\title{
Correction to: A note on Dekker's FastTwoSum algorithm
}

\author{
Marko Lange ${ }^{2} \cdot$ Shin'ichi Oishi ${ }^{1}$
}

Published online: 4 September 2021

(C) The Author(s) 2021

\section{Correction to: Numerische Mathematik (2020) 145:383-403 https://doi.org/10.1007/s00211-020-01114-2}

The article "A note on Dekker's FastTwoSum algorithm", written by Marko Lange and Shin'ichi Oishi, was originally published Online First without Open Access. After publication in volume 145, issue 2, page 383-403 the author decided to opt for Open Choice and to make the article an Open Access publication. Therefore, the copyright of the article has been changed to (C) The Author(s) 2020 and the article is forthwith distributed under the terms of the Creative Commons Attribution 4.0 International License, which permits use, sharing, adaptation, distribution and reproduction in any medium or format, as long as you give appropriate credit to the original author(s) and the source, provide a link to the Creative Commons licence, and indicate if changes were made. The images or other third party material in this article are included in the article's Creative Commons licence, unless indicated otherwise in a credit line to the material. If material is not included in the article's Creative Commons licence and your intended use is not permitted by statutory regulation or exceeds the permitted use, you will need to obtain permission directly from the copyright holder. To view a copy of this licence, visit http://creativecommons.org/ licenses/by/4.0.

Open access funding enabled and organized by Projekt DEAL.

Original article has been corrected.

The original article can be found online at https://doi.org/10.1007/s00211-020-01114-2.

Shin'ichi Oishi

oishi@waseda.jp

Marko Lange

m.lange@tuhh.de

1 Faculty of Science and Engineering, Waseda University, 3-4-1 Okubo, Shinjuku-ku, Tokyo 169-8555, Japan

2 Institute for Reliable Computing, Hamburg University of Technology, Am Schwarzenberg-Campus, 3, 21073 Hamburg, Germany 
Open Access This article is licensed under a Creative Commons Attribution 4.0 International License, which permits use, sharing, adaptation, distribution and reproduction in any medium or format, as long as you give appropriate credit to the original author(s) and the source, provide a link to the Creative Commons licence, and indicate if changes were made. The images or other third party material in this article are included in the article's Creative Commons licence, unless indicated otherwise in a credit line to the material. If material is not included in the article's Creative Commons licence and your intended use is not permitted by statutory regulation or exceeds the permitted use, you will need to obtain permission directly from the copyright holder. To view a copy of this licence, visit http://creativecommons.org/ licenses/by/4.0/.

Publisher's Note Springer Nature remains neutral with regard to jurisdictional claims in published maps and institutional affiliations. 